\title{
EVALUASI PROGRAM PENDIDIKAN INKLUSI PENDIDIKAN DASAR SEKOLAH SIF AL FIKRI DEPOK (Penerapan Model Evaluasi Stake)
}

\author{
Jajang Permana Jaya \\ Universitas Islam 45
}

Agus Dudung

Universitas Negeri Jakarta

Dinny Devi Triana

Universitas Negeri Jakarta

\begin{abstract}
The purpose of this research was to evaluate the inclusion education program in year 2016/2017. The evaluation used Robert E. Stake model which consist of antecedent, transaction, and outcomes. This research was held in Sekolah Islam Fitrah Al Fikri Depok. The data were collected by using questioner, interview, observation, and documentations instrument. The results of this research showed that: (I) Antecedents: generally in high category. From all aspects which evaluated were in high category and just one aspect in medium category. The main and supporting facilities were very adequate, and physically in very good category; (2) Transaction: generally in high category. Based on the result of the assessment process obtained mean score 66,77 (80,29\%) in high category, that was 53,33 < $X$; and (3) Outcomes: the special need students achievement in SIF Al-Fikri were in high category.
\end{abstract}

Keywords: Inclusion education program, Stake Evalation Model

\begin{abstract}
ABSTRAK
Tujuan penelitian ini adalah mengevaluasi program Program Pendidikan Inklusi Tahun Akademik 2016/2017. Evaluasi ini menerapkan model Robert E. Stake, meliputi: antecedents, transaction, dan outcomes. Penelitian dilaksanakan di Sekolah Islam Fitrah AL Fikri Depok. Pengumpulan data penelitian dilakukan dengan menggunakan instrumen yaitu: angket, wawancara, observasi, dan studi dokumentasi. Hasil penelitian menunjukkan bahwa: (I) Antecedents: Secara umum kategori tinggi. Dari semua aspek yang dinilai ada pada kategori tinggi dan hanya satu aspek ada pada kategori sedang. Fasilitas utama dan pendukung kategori sangat memadai, dan evaluasi terhadap kondisi fisik sarana dan prasarana kategori sangat baik; (2) Transaction: Secara umum kategori tinggi. Berdasarkan hasil penilaian tersebut diperoleh skor rata-rata sebesar 66,77 $(80,29 \%)$ termasuk ke dalam kategori tinggi, yaitu $53,33 \leq X$; dan (3) Outcomes: hasil belajar siswa ABK di SIF AL-Fikri termasuk ke dalam kategori tinggi.
\end{abstract}

Kata kunci: Program Pendidikan Inklusi, evaluasi model Stake
Alamat Korespondensi Jl. Puntodewo no. 434 RT /RW. 003/002 Halim Perdana Kusuma, Makasar Jakarta Timur, DKI Jakarta Indonesia e-mail: Jajangpermanajaya@Gmail.co $\mathrm{m}$
siswa.Dengan dukungan Lembaga Learning Support Center (LSC) yang dimiliki SIF AL Fikri diharapkan Kegiatan Belajar Mengajar siswa berkebutuhan khusus ini akan lebih optimal. LSC bertujuan memayungi segala kebutuhan dan memberikan layanan bagi $A B K$ dan orang tua $A B K$. Diantara mereka ada yang masih menggunakan guru pendamping (aide teacher) dan ada juga yang sudah mandiri tanpa menggunakan guru pendamping khusus disertai dengan program/kurikulum individu yang disusun bersama pihak yang terkait seperti; guru pendamping (aide teacher), guru kelas, psikolog dan orang tua. Lembaga Learning Support Centre (LSC) mempunyai fungsi diantaranya: mengembangkan Program Pembelajaran Individual (PPI)/Individual siswa Al Fikri dengan kurikulum dan program yang
disesuaikan dengan kebutuhan masing-masing yang berpusat pada nilai-nilai spiritual. Salah satu komitmen SIF AL Fikri adalah memberlakukan pendidikan inklusi. Dengan demikian anak-anak berkebutuhan khusus akan tetap menjadi bagian dari 
Jajang Permana Jaya

Agus Dudung

Dinny Devi Triana

Educational Plan (IEP). Memantau perkembangan anak, mengkoordinir jalannya program pengayaan atau remedial, mengkoordinasikan tenaga ahli khusus, seperti: psikolog, guru pendamping (aide teacher), serta mengadakan sesi pelatihan bagi semua guru dan orang tua. Lembaga ini juga sebagai pengatur jadwal untuk sebuah pertemuan rutin antara guru, psikolog, guru pendamping (aide teacher) dan orang tua dalam rangka menyusun program, melakukan evaluasi, menyelesaikan permasalahan yang ditemui selama proses pembelajaran berlangsung. Lembaga ini diharapkan dapat membantu mengoptimalkan potensi siswa berkebutuhan khusus, sehingga anak berkebutuhan khusus dapat berkembang memenuhi tahapan perkembangan usia dan dapat mandiri di kehidupan sehari-harinya.

Namun, pada kenyataannya dalam mengatasi ABK membutuhkan keahlian tersendiri karena tidak semua aktivitas di sekolah dapat diikuti oleh anak tersebut, misalnya anak autis tidak dapat mengikuti pelajaran karena tidak mampu mengendalikan diri dalam mengatur emosinya. Oleh karena itu dibutuhkan Guru pendamping Khusus (GPK) yang mampu memahami sekaligus menangani keberadaan $A B K$ termasuk didalamnya memahami karakter dari masing-masing jenis kecatatannya. $\mathrm{Di}$ samping membutuhkan guru khusus, juga permasalahan-permasalahan yang dihadapi program pendidikan inklusi pada umumnya berkaitan dengan model pembelajaran yang tepat. Program pendidikan inklusi merupakan sistem penyelenggaraan pendidikan yang memberikan kesempatan kepada semua peserta didik yang memiliki kelainan dan memiliki potensi kecerdasan dan/atau istimewa untuk mengikuti pendidikan dalam satu lingkungan pendidikan secara bersama-sama dengan peserta didik pada umumnya. Berarti guru harus dapat menentukan model pembelajaran yang dapat mengakomodasi kebutuhan belajar bersama-sama dalam satu ruang antara anak berkebutuhan khusus dengan anak normal pada umumnya. Oleh karena itu di kelas terapat keterkaitan yang erat antara guru dan siswa dalam proses belajar mengajar.

Tugas guru adalah memilih model dan metode pembelajaran yang tepat sesuai dengan materi yang disampaikan dan karakteristik siswa, demi tercapainya tujuan pembelajaran. Dengan model pembelajaran yang
Evaluasi Program Pendidikan Inklusi Pada Pendidikan Dasar Sekolah Islam Fitrah Al Fikri Depok (Penerapan Model Evaluasi Stake)

sesuai diharapkan pemahaman siswa terhadap materi pelajaran yang diberikan dapat ditingkatkan, sehingga hasil belajar yang diperoleh dapat maksimal. Penyelenggaraan program sekolah inklusi tidak sesederhana menyelenggarakan sekolah umum. Kenyataan di lapangan harus menyiapkan sarana dan prasarana yang cukup. Misalnya: gedung sekolah menyesuaikan kondisi anak. Peralatan yang memadai. Fenomena lain, apakah kurikulum yang diterapkan telah sesuai dengan kurikulum yang dikembangkan oleh satuan pendidikan di bawah standar nasional pendidikan. Apakah penyelenggaraan program pendidikan inklusi menggunakan kurikulum yang dapat mengakomodasi kebutuhan dan kemampuan anak berkebutuhan khusus. Bertitik tolak dari permasalahan diatas, maka penulis tertarik untuk mengadakan Evaluasi mengenai "Evaluasi Program Pendidikan Inklusi sebagai Sistem Pembelajaran bagi Anak Berkebutuhan Khusus (ABK) di Sekolah Islam Fitrah (SIF) Al Fikri Depok" Evaluasi ini diharapkan dapat mengukur apakah Penyelenggaraan Program Pendidikan Inklusi di SIF AL Fikri telah memenuhi standar nasional bagi anak berkebutuhan khuus dan dapat dijadikan sebagai acuan dalam pengambilan keputusan mengenai Program Pendidikan Inklusi diteruskan, diubah, dikembangkan atau dihentikan.

Penelitian ini difokuskan hanya pada evaluasi program pendidikan inklusif dengan menggunakan evaluasi model Stake's Continances yang dikembangkan oleh Robert E Stake sebagaimana dikutif Wirawan. Model desain penelitian kualitatif ini menggunakan model Countenances Evaluation oleh Stake yang menekankan adanya dua hal pokok yaitu: (I) Deskripsi (description) dan (2) pertimbangan (Judgement) serta membedakan adanya tiga tahap dalam evaluasi program , yaitu (I) anteseden (antecedences), (2) transaksi (transaction) dan (3) keluaran (outcomes).(arikunto dan cepi,2007). Tujuan penelitian ini adalah untuk mendapatkan informasi yang komprehensip terhadap efektifitas pelaksanaan dan keberhasilan program pendidikan inklusif di sekolah SIF AL Fikri dengan mendeskripsikan dan menilai setiap komponen antecedence, transaction dan outcomes. Istilah Inklusi berasal dari bahasa inggris "inclusion" yang dapat berarti sebagai penerimaan anak-anak yang memiliki hambatan ke dalam kurikulum, lingkungan, interaksi sosial dan 
Jajang Permana Jaya

Agus Dudung

Dinny Devi Triana

konsep diri atau visi misi sekolah (Smith, 2009). Inklusif juga dapat diartikan sebagai cara berfikir dan bertindak yang memungkinkan setiap individu merasakan diterima dan dihargai. Lebih jauh lagi inklusif berarti bahwa semua anak dapat diterima meskipun konsep "semua anak" harus cukup jelas, dan masih sulit bagi banyak orang untuk memahaminya (Sapon-Shepin, 2007). Adapun pengertian pendidikan inklusif sendiri adalah suatu cara untuk menghilangkan model segregasi atau pemisahan anak-anak berkelainan yang belajar dengan cara yang berbeda (Khalsa, 2004). Pendapat lainnya mendefinisikan pendidikan inklusif adalah sebagai sistem layanan pendidikan yang mempersyaratkan agar semua anak berkelainan dilayani di sekolah-sekolah terdekat di kelas reguler bersama-sama teman seusianya (SaponShepin dikutip Geniofam, 2010). Sedangkan menurut Depdiknas menegaskan bahwa pendidikan inklusif didefinisikan sebagai Sistem layanan pendidikan yang mengikutsertakan anak berkebutuhan khusus belajar bersama dengan anak sebayanya di sekolah reguler yang terdekat dengan tempat tinggalnya (Depdiknas, 2007). Dengan demikian penyelenggaraan pendidikan inklusif menuntut pihak sekolah untuk melakukan penyesuaian baik dari segi kurikulum, sarana prasarana pendidikan, maupun sistem pembelajaran yang disesuaikan dengan kebutuhan dan karakteristik peserta didik (siswa).

Dalam Permendiknas No. \&) tahun 2009 pasal 2 ayat I dan 2 menyatakan 4 Tujuan penyelenggaraan pendidikan inklusif adalah untuk memberikan kesempatan yang seluas-luasnya kepada semua peserta didik yang memiliki kelainan fisik, emosional, mental dan sosial atau memiliki potensi kecerdasan dan atau bakat istimewa untuk memperoleh pendidikan yang bermutu sesuai kebutuhan dan kemampuannya, selain itu untuk mewujudkan penyelenggaraan pendidikan yang menghargai keanekaragaman, dan tidak diskriminatif bagi semua peserta didik. Adapun tujuan lain diselenggarakannya pendidikan inklusif ini adalah untuk memberikan kesempatan yang setara berupa layanan pendidikan yang efektif kepada semua siswa termasuk mereka yang memiliki kelainan dengan alat bantu tambahan yang diperlukan sesuai usia dan kelas dilingkungan mereka dengan tujuan untuk mempersiapkan siswa untuk hidup secara produktif sebagai anggota masyarakat (Lipsky \& Gartner dikutip
Evaluasi Program Pendidikan Inklusi Pada Pendidikan Dasar Sekolah Islam Fitrah Al Fikri Depok (Penerapan Model Evaluasi Stake)

Depdiknas, 2009). Sedangkan yang menjadi landasan acuan penyelenggaraan pendidikan inklusif adalah landasan filosofis, landasan yuridis, landasan pedagogis dan landasan empiris (Depdiknas, 2009:). Dalam setting penyelenggaraan program pendidikan inklusif di sekolah reguler terdapat sejumlah anak berkebutuhan khusus yang merupakan sebagian kecil dari jumlah peserta didik (siswa) yang bersekolah.

Anak berkebutuhan khusus adalah anak yang dalam pendidikan memerlukan pelayanan yang spesifik, berbeda dengan anak pada umumnya (Depdiknas, 2007). Anak berkebutuhan khusus juga didefinisikan sebagai anak yang mempunyai karakteristik yang berbeda antara satu dan lainnya.(Delphie, 2010), Sedangkan pendapat lain menyebutkan anak berkebutuhan khusus adalah anak yang dianggap memiliki kelainan penyimpangan dari kondisi rata-rata anak normal umumnya, baik hal fisik, mental maupun karakteristik perilaku sosialnya (Efendi, 2006). Katagori anak berkebutuhan khusus dalam aspek fisik meliputi anak dengan kelainan indera mata (tunanetra), kelainan kemampuan bicara (tunarungu), dan kelainan fungsi anggota tubuh (tunadaksa). Adapun Katagori ABK dalam aspek mental meliputi anak yang memiliki kemampuan mental lebih atau unggul (Cerdas Istimewa/Bakat Istimewa), dan memiliki kemampuan mental sangat rendah (tunagrahita). Sedangkan katagori ABK dalam aspek sosial adalah anak yang memiliki kesulitan dalam menyesuaikan perilakunya terhadap lingkungan sekitar yang disebut juga anak tunalaras (Efendi, 2006).

Evaluasi merupakan suatu proses menyediakan informasi yang dapat dijadikan sebagai pertimbangan untuk menentukan harga dan jasa dari tujuan yang dicapai, desain, implementasi dan dampak untuk membantu membuat suatu keputusan, membantu pertanggungjawaban dan meningkatkan pemahaman tentang phenomena yang terlibat (Stufflebeam dan Shinkfield, 1985). Evaluasi juga merupakan proses yang berkaitan dengan penyiapan berbagai wilayah keputusan melalui pemilihan informasi yang tepat, pengumpulan dan analisis data, serta pelaporan yang berguna bagi para pengambil keputusan (Alkin dikutip Sudjana, 2008). Pendapat lainnya tentang definisi evaluasi adalah usaha untuk menentukan manfaat atau kegunaan sosial dari 
Jajang Permana Jaya

Agus Dudung

Dinny Devi Triana

kebijakan atau program, dan bukan sekedar mengumpulkan informasi tentang keluaran tindakan kebijaksanaan baik yang diperkirakan sebelumnya maupun yang tidak diperkirakan (Dunn, 2003).

Evaluasi juga didefinisikan sebagai identifikasi, 5 klarifikasi dan penerapan kriteria untuk menentukan nilai suatu obyek yang dievaluasi baik berupa nilai maupun jasa dalam kaitannya dengan kriteria tersebut (Fitzpatrick, Sander dan Worthen, 2004). Sedangkan menurut Owen evaluasi merupakan suatu penilaian layak dari sebuah program dan hasil pengetahuan berdasarkan penelitian secara sistematis untuk membantu pengambilan keputusan tentang suatu program (Owen, 2006). Tujuan evaluasi adalah untuk mengumpulkan informasi dan menentukan nilai dan manfaat obyek evaluasi, mengontrol, memperbaiki dan mengambil keputusan mengenai obyek (Wirawan, 20II). Evaluasi juga bertujuan untuk memperoleh informasi yang akurat dan obyektif tentang suatu program (Widoyoko, 20II). Selain tujuan tersebut evaluasi juga memiliki tujuan lainnya yaitu untuk menunjukkan pada penggunaan metode penelitian, menekankan pada hasil suatu program, penggunaan kriteria untuk menilai dan memberikan kontribusi terhadap pengambilan keputusan dan perbaikan program di masa mendatang (Widoyoko (20II).

Program adalah kegiatan atau aktivitas yang dirancang untuk melaksanakan kebijakan yang dilaksanakan untuk waktu yang tidak terbatas (Wirawan, 20II). Program juga didefinisikan sebagai suatu unit atau kesatuan kegiatan yang merupakan realisasi atau implementasi dari suatu kebijakan, berlangsung dalam proses yang berkesinambungan dan terjadi dalam suatu organisasi yang melibatkan sekelompok orang (Suharsimi, 2009). Adapun evaluasi program merupakan evaluasi yang menilai suatu aktivitas di bidang pendidikan dengan menyediakan data yang berkelanjutan (Widoyoko, 20I I). Evaluasi program juga didefinisikan sebagai upaya menyediakan informasi untuk disampaikan kepada pengambil keputusan ( Cornbach dikutip Suharsimi, 2009). Sedangkan pendapat selanjutnya mendefinisikan evaluasi program adalah metode sistematis untuk mengumpulkan, menganalisis dan memakai informasi untuk menjawab pertanyaan dasar mengenai program (Wirawan, 20II). Sependapat
Evaluasi Program Pendidikan Inklusi Pada Pendidikan

Dasar Sekolah Islam Fitrah Al Fikri Depok (Penerapan Model Evaluasi Stake)

dengan Wirawan, evaluasi program dapat pula didefinisikan sebagai kegiatan sistematis untuk mengumpulkan, mengolah, menganalisis dan menyajikan data sebagai masukan untuk pengambilan keputusan (Sudjana, 2008). Adapun pendapat lainnya menegaskan bahwa evaluasi program merupakan kegiatan pengumpulan data atau informasi secara sistematis tentang bagaimana program tersebut berjalan, tentang dampak yang mungkin terjadi atau menjawab pertanyaanpertanyaan yang diminati (Farida Yusuf, 2008).

Dalam penelitian evaluative tentang pelaksanaan Sitem Pendidikan inklusif ini, Model yang digunakan adalah Countenence Evaluation Models yang dikembangkan oleh Stake. Suharmi dan Cepi menjelaskan dua hal poko, yaitu : (I) deskripsi (Description) dan (2) Pertimbangan (Judgment), serta membedakan adanya tiha tahap evaluasi dalam evaluasi program yaitu (I) antesenden (antecendent/comtex),

transaksi

transaction/proses), dan (3) keluaran (outpuytoutcomes). Countenence Evaluation model yang dikembangkan oleh stake mengumpulkan serangkaian informasi yang sekriptif dan mengandung unsur pertimbangan dari suatu objek. Antecedent mengacu pada latar belakang informasi yang berhubungan, tipe imformasi ini termasuk kondisi yang ada sebelum belajar mengajar yang bisa saja berhubungan dengan outcomes, sedangkan transaction termasuk pertemuan antara siswa dengan guru. $\mathrm{Di}$ dalamnya mengatur segala peristiwa proses evaluasi agar mengetahui program kerja terbaru. Outcomes (hasil akhir) berhubungan dengan apa yang didapatkan dri sebuah program. Selanjutnya keedua matrik yang digambarkan sebagai deskripsi dan pertimbangan, menunjukan langka-langkah yang terjadi selama proses evaluasi.

Matrik pertama, yaitu deskripsi menyangkut dua hal yang menu jukan posisi sesuatu (yang menjadi sasaran evaluasi), yaitu apa maksud/tujuam yang diharapkan oleh program dan pengamatan/akibat, yaitu apa yang sesungguhnya terjadi atau apa yang betul betul terjadi. Selanjutnya evaluator mengikuti matrik kedua, yang menunjukan langkah pertimbangan yang dalam langkajh tersebut mengacu pada standar. 
Jajang Permana Jaya

Agus Dudung

Dinny Devi Triana

Menurut Stake yang dikutip Arikunto dan Cepi, ketika evaluator tengah mempertimbangkan program pendidikan, mereka mau tidak mau harus melakukan dua perbandingan, yaitu : (I) membandingkan kindisi hasil evaluasi program tertentu dengan yang terjadai deprogram lain., dengan objek dan sasaran yang sam, dan (2) membandingakn kondsi hasil pelaksanaan program dengan standar yang diperuntukan bagi proram yang bersangkutan, didasarkan pada tujuan yang akan di capai. Secara fundamental, mengevaluasi suatu program akan diwarnai dengan deskripsi dan pertimbangan. Sseperti yang dijelaskan oleh Stufflebeam dan Shinkfield, bahwa countenance evaluation model meliputi : I) description dan judgement of a program (deskripsi dan pertimbangandari suatu program); (2) $a$ variety of data source (aneka ragam sumber data);(3) analysis of congruence and contingencies (analisi kongruensi dan kontingensi); (4)identification of pertinent, oftenconfcting standart (mengindetifikasi hubungan yang kerap kali bertentangan dengan standar), (5) multiple used of evaluation (manfaat-manfaat ganda dari evaluation). Untuk menjalankan model ini dapat diketahui congruence kesamaan antara apa yang diharapkan dengan apa yang nyata menurut observasi para ahli penilaian. Selain itu juga diselidiki contingency atau hubungan antara anteseden, tranksaksi, dan hasil belajar seperti yang diterapkan dan diobservasi. Pada bagian observasi hubungan antara ketiga aspek itu (anteseden, transaksi dan hasil) diselidiki berdasarkan data yang nyata.

Menurut Tyler sebagaimana dikutip oleh Guba dan Lincoln bahwa evaluasi adalah proses menentukan sejauh mana tujuan-tujuan pendidikan terealisasikan secara actual. Lebih jauh Stake menjelaskan juga didalam Guba dan Lincoln menyatakan bahwa sedikitnya ada lima tujuan diadakannyanya evaluasi yaitu : (I) Sebagai dokumen kejadian-kejadian, (2) sebagai catatan perubahan siswa, (3) untuk membantu dalam membuat keputusan, (4) untuk meningkatkan pemahaman, dan (5) untuk memfasilitasi kegiatan perbaikan.

Selain itu, berkaitan dengan pemilihan rancangan evaluasi Patton mengungkapkan bahwa tidak ada jawaban yang seerhana segera dan menyeluruh terhadap pertanyaan tentang rancangan atau strategi evaluasi ,ama yang paling baik. Menurut Patton, jawaban
Evaluasi Program Pendidikan Inklusi Pada Pendidikan Dasar Sekolah Islam Fitrah Al Fikri Depok (Penerapan Model Evaluasi Stake)

setiap kasus akan tergantung pada apa yang ingin diketahui oleh para pemangku kepentingan, tujuan evaluasi, dana yang tersedia, dan minat/kemampuan/ bias atas keterlibatan evaluator.

Dalam mengevaluasi suatu program, metode kualitatif dapat sangat mempertinggi pemanfaatan temuan evaluasi karena datannya betul betul dipertimbangkan secara personal. Dari beberapa definisi di atas, maka tiga hal pada countenance evaluation models yang harus mampu diidentifikasi oleh evaluator yaiitu antecedent, transaction dan outcomes.

\section{a. Evaluasi Antecedent}

Orientasi utama dari evaluasi antecedent yang diartikan sebagai evalusi konteks adalah untuk mengidentifikasi kekuatan dan kelemahan suatu objek, seperti institusi, program, populasi target, atau orang, dan juga untuk menyediakan arahan untuk perbaikan. Antecedent merupakan keadaan persyaratan sebelum proses berlangsung yang berpengaruh terhadap hasil yang diharpkan tercapai. Indikator yang menjadi fokus dalam mengevaluasi konteks program penelitian terdiri dari: landasan formal, tujuan pendidikan, manajemen sekolah, tenaga pendidik, keterangan sekolah, kurikulum, ketersedian sarana dan prasarana, pembiayaan serta dukungan orang tua dan masyaralkat.

\section{b. Evaluasi Transaction}

Evaluasi transaction yang diartikan sebagai evaluasi proses merupakan evaluasi yang dilakukan untuk melihat apakah pelaksanaan program sesuai dengan srategi yang telah direnacanakan.

Evaluasi transaction bertujuan untuk mengidentifikasi atau memprediksi dalam proses pelaksanaan, seperti cacat dalam prosedur atau implementasinya. Evaluasi transaction juga bertujuann untuk menyediakan informasi sebagai dasar memperbaiki program, serta untuk mencatat, dan menilai prosedur kegiatan dan peristiwa. Evaluasi ini dapat dilakuakn dengan mengobservasi kegiatan dan dokumentasi terhadap pelaksanaan kegiatan belajar mengajar, yang mencakup perencanaan, pelaksanaan, penilaian dan pengawsa terhadap pembelajaran.

c. Evaluasi Outcomes

Evaluasi outcomes yang diartikan sebagai evaluasi hasil adalah evaluasi yang bertujuan untuk mengukur, 
Jajang Permana Jaya

Agus Dudung

Dinny Devi Triana

menginterprestasikan, dan menilai pencapaian program. Evaluasi outcomes dalam penelitian berupa hasil belajar siswa yang meliputi nilai hasil belajar siswa serta informs ketercapaian tujuan pembelajaran sebagaimana yang telah dirumuskan dalam melaksanakan suatu pembelajaran. Evaluasi outcomes juga bertujuan untuk mengumpulkan deskripsi dan penilaian terhadap keluaran (outcomes) dan menghubungkan itu semua dengan entecedent, dan informasi transaction, serta untuk menginterprestasikan kelayakan dan keberhargaan program.

\section{Metode Penelitian}

Tujuan Evaluasi ini adalah untuk mengetahui penyelenggaraan program pendidikan inklusi yang memenuhi Standar Nasional Pendidikan Inklusi, meliputi; komponen-komponen apa saja yang dapat menunjang keberhasilan program pendidikan inklusi tersebut. Dan untuk mengetahui sejauhmana program pendidikan inklusi dapat mengembangkan potensi kecerdasan anak berkebutuhan khusus secara optimal. Pendekatan yang digunakan adalah goal oriented approach yaitu pendekatan berorientasi pada tujuan yang mana menggunakn tujuan program sebagai kriteria untuk menentukan keberhasilan.

Metode dalam penelitian evaluasi ini menggunakan metode studi kasus (Case studi) yang merupakan bagian dari penelitian kualitatif. Lebih menfokuskan hanya pada efektifitas pelaksanaan programnya saja.

Model Evaluasi yang digunakan yaitu Stake's Countenance Model yang dikembangkan oleh Robert E. Stake. Evaluasi model ini terdiri dari tiga tahapan yaitu; Masukan (antecendent), Proses (transaction) dan hasil (outcomes).

Evaluasi program pendidikan Inklusi di SIF Al Fikri Depok teknik pengumpulan datanya bersifat menghimpun yaitu: berupa angket dengan responden Guru reguler dan GPK; untuk wawancara responden Principal, Kepala sekolah dan Wakil kepala sekolah kurikulum maupun kesiswaan; observasi dan dan daftar inventory untuk menilai kondisi sarana dan prasarana; studi dokumentasi mengecek keberadaan beberepa dolkumen.

Hasil dari semua itu diolah dan simpulkan dengan teori yang lazim digunakan.
Evaluasi Program Pendidikan Inklusi Pada Pendidikan Dasar Sekolah Islam Fitrah Al Fikri Depok (Penerapan Model Evaluasi Stake)

\section{Hasil Penelitian dan Pembahasan}

Evaluasi Komponen Antecedents (Konteks dan Input), Proses identifikasi dan asesmen telah memnuhi standar, diantaranya SIF AL Fikri melakukan proses identifikasi dan asesmen dengan tujuan untuk penjaringan, Klasifikasi siswa $A B K$ sesuai dengan jenis hambatan dan penempatan siswa $A B K$ pada setiap rombongan belajar serta untuk menyusun perencanaan pembelajran yang sesuai dengan hasil identifikasi dan asesmen. Keberadaan guru regular dan GPK sudah memenuhi standar, karena dari hasil penilaian diperoleh bahwa sebagian besar guru-guru yang mengajar di SIF AL Fikri memeiliki latar belakang poendidikan dan untuk GPK walaupun tidak memiliki latar belakang pendidikan lua biasa namun GPK yang ada di SIF sering mengikuti pelatihan khusus baik didalam maupun di luar sekolah. Kurikulum yang digunakan dalam program yang dikembangkan sesuai dengan landasan pengembangan kurikulum pendidikan inklusi, yang termasuk kedalam kategori tinggi dengan kata lain telah memenuhi standar, karena kurikulum disusun dan dikembangkan sesuai dengan kemampuan dan kebutuhan siswa $A B K$. Kurikulum dikembangkan berdasarkan kopetensi dasar yang lebih disederhanakan, indicator, materi, bentuk evaluasi, materi pembelajaran, dan standar ketuntasan minimal (SKM).

Sarana dan prasarana yang dimiliki SIF AL Fikri secara umum telah memenuhi standar. Dalam implementasi pendidikan inklusif, sekolah melibatkan pihak pihak lain dari luar sekolah untuk membantu kelancaran dalam penyelenggaran pendidikan inklusif di antaranya orang tua siswa. Dukungan orang tua siswa sangatlah penting dalam menunjang proses pembelajaran siswa ABK. Evaluasi Komponen Transaction (Proses), Hasil kuesioner instrumen transaction berdasarkan aspek yang mencakup proses pembelajaran, yang terdiri dari : hasil evaluasi terhadap perencanaan pembelajaran, kegiatan pembelajaran (pendahuluan, inti dan penutup), sedangkan penilaian pembelajaran menggunakan teknik yang sesuai dengan karakteristik dan kemampuan siswa ABK. Evaluasi Komponen Outcomes (Hasil). Hasil kuesioner instrumen outcomes yang terdiri dari aspek hasil belajar yang meliputi sistem kenaikan kelas/kelulusan dan sistem pelaporan siswa $A B K$ dalam bentuk quntitatif dan 
Jajang Permana Jaya

Agus Dudung

Dinny Devi Triana

deskripsi, yang akan dinilai melalui studi dokumen. Model kenaikan kelas yang digunakan di SIF Al Fikri adalah berdasarkan usia kalender peserta didik (cronologi age), yaitu sistem kenaikan kelas secara otomatis (otomatic promotion) sesuai dengan pertumbuhan fisik dan perkembangan kematangan sosila psikologis peserta didik. Sedangkan sistem pelaporan hasil belajar disesuaikan dengan kurikulum yang digunakan. Standar yang digunakan untuk menilai hasil belajar siswa $A B K$ disesuaikan dengan jenis hambatan, Kurikiulum yang digunakan dan standar yang berlaku di sekolah yang bersangkutan.

Berdasarkan rekapitulasi hasil belajar yang menggunakan dokumen rapport dengan standar yang disesuaikan dengan kemampuan siswa $A B K$, dapat disimpulkan bahwa hasil belajar siswa ABK di SIF AL Fikri termasuk kedalam kategori tinggi.

\section{Kesimpulan dan Rekomendasi Kesimpulan}

Berdasarkan hasil penelitian dan pembahasan dapat disimpulkan berdasarkan tiga bagian sesuai komponen antecedent, transaction dan outcomes. Hasil penelitian pada komponen antecedent menunjukkan bahwa antecedent, pada aspek siswa ABK memiliki keberagaman jenis kelainan sebagai hasil dari proses identifikasi dan asesmen. Justifikasi bahwa seorang siswa disebut $A B K$ memerlukan identifikasi dan asesmen yang mendalam.

Identifikasi dan asesmen bertujuan untuk penjaringan, mengetahui jenis hambatan dan penempatan siswa $A B K$ pada setiap rombongan belajar, tanpa ada kegiatan identifikasi dan asesmen, maka akan berdampak pada kesalahan dalam treatmen dan perencanaan pembelajaran. Asesmen berfungsi untuk mengetahui bahwa seorang siswa diduga sebagai $A B K$, sedangkan kepastiannya harus ditetapkan oleh hasil tes yang dilakukan oleh professional. Dari keberadaan guru menunjukkan bahwa guru-guru yang mengajar di SIF AL-Fikri sebagian besar memiliki latar belakang pendidikan, dan untuk keberadaan GPK SIF AL Fikri tidak memiliki latar belakang pendidikan PLB namun telah mengikuti diklat inklusi. Sehingga para GPK memiliki kemampuan dalam memperdayakan potensi atau keahlian yang dimiliki GPK. Kurikulum yang
Evaluasi Program Pendidikan Inklusi Pada Pendidikan Dasar Sekolah Islam Fitrah Al Fikri Depok (Penerapan Model Evaluasi Stake)

digunakan dalam penyelenggaraan pendidikan inklusif pada dasarnya menggunakan kurikulum regular yang berlaku di sekolah umum. Namun demikian karena ragam hambatan yang dialami peserta didik berkebutuhan khusus sangat bervariasi, mulai dari yang sifatnya ringan, sedang sampai yang berat, maka dalam implementasinya, kurikulum regular perlu dilakukan modifikasi (penyelarasan) sedemikian rupa sehingga sesuai dengan kebutuhan peserta didik.

Modifikasi kurikulum dilakukan oleh tim pengembang kurikulum di sekolah. Tim pengembang ini terdiri dari kepala sekolah, guru kelas, guru mata pelajaran, guru pembimbing khusus, konselor, psikolog dan ahli lain yang terkait. Modifikasi yang dilakukan adalah perlunya adaptasi silabus dan RPP agar pembelajaran bersifat adaptif dan akomodatif terhadap keragaman peserta didik. Selain silabus dan RPP untuk siswa $A B K$ yang tidak menggunakan kurikulum standar harus ditetapkan program pembelajaran individual. Aspek sarana dan prasarana ditemukan bahwa sarana dan prasarana khusus tidak memadai, bahkan banyak yang tidak dimiliki, hal ini berdampak pada proses pembelajaran. Kebutuhan dasar pada aspek sarana dan prasarana program pendidikan inklusi adalah ruang khusus untuk layanan pembelajaran yang sesuai dengan kemampuan dan kebutuhan siswa $A B K$ bangunan yang aksesibel, media dan alat peraga khusus.

Media pembelajaran merupakan aspek yang penting serta bangunan yang mudah dijangkau oleh siswa $A B K$ dan memiliki sifat aksesibel, sedangkan sarana dan prasarana yang tidak memadai atau belum ada, dapat diupayakan secara bertahap. Hasil penelitian pada komponen transactions hasil penelitian menunjukkan bahwa aspek perencanaan pembelajaran termasuk ke dalam kategori tinggi dengan perolehan skor rata-rata sebesar 58,54 (81,31\%). Melihat kondisi dari siswa ABK di SIF AL-Fikri, pengelolaan kelas dengan menggunakan model pull out dirasa lebih sesuai bagi siswa ABK disana. Model kelas ini dirasa dapat mudah disesuaikan dengan hambatan yang dimiliki oleh siswa dalam kemampuan belajarnya.

Kegiatan pembelajaran terdiri dari 3 tahapan, yaitu tahapan pendahuluan, kegiatan inti dan penutup. Kegiatan pembelajaran dinilai telah sesuai dengan perencanaan pembelajaran yang telah disusun 
Jajang Permana Jaya

Agus Dudung

Dinny Devi Triana

sebelumnya, yaitu berdasarkan perolehan skor rata-rata sebesar 69 (75\%) termasuk ke dalam kategori sedang perlakuan yang sesuai. Penilaian pembelajaran, termasuk ke dalam kategori sedang dengan perolehan skor ratarata sebesar 2,83 $(70,68 \%)$, artinya telah memenuhi standar penilaian pembelajaran dengan menggunakan teknik penilaian yang sesuai dengan karakteristik dan kemampuan siswa ABK.

Rata-rata tingkat pencapaian hasil belajar yang diperoleh siswa $A B K$ cukup baik, artinya bahwa siswa $A B K$ dapat dinyatakan naik kelas, namun hasil yang diperoleh jauh dari rata-rata yang diperoleh dari seluruh peserta didik yang ada di sekolah tersebut. Akan tetapi, dalam hal pelaporan masih menggunakan raport yang standar yang sudah ada, namun agar dapat dipahami secara kualitatif prestasi siswa $A B K$ yang sebenarnya maka raport harus dilengkapi dengan keterangan naratifkualitatif yang menggambarkan perkembangan prestasi siswa $A B K$. Standar penilaian hasil belajar disesuaikan dengan kurikulum yang dipakai dan karakteristik siswa ABK.

\section{A. Rekomendasi}

\section{Antecedent}

Pencatatan, pendokumentasian dan pengadministrasian atas hasil identifikasi dan asesmen masih perlu dilakukan dengan rapi dan tertib, sehingga dari awal pihak sekolah sudah dapat mengidentifikasi siapa saja siswa yang terjaring ke dalam siswa $A B K$, maka pihak sekolah dengan mudah dapat menentukan perencanaan pembelajaran yang sesuai dengan karakteristik dan kemampuan siswa ABK.

Pengembangan kurikulum regular yang sesuai dengan kebutuhan dan kemampuan siswa ABK perlu dilakukan, terutama kurikulum program pembelajaran individual yang akan menangani siswa $A B K$ secara perorangan. Sebagaimana kita ketahui bahwa siswa ABK memiliki bermacam keunikan masing-masing. Akan tetapi, lebih baik jika pemerintah menyusun kurikulum khusus yang akan digunakan dalam penyelenggaraan program pendidikan inklusi. Sarana dan prasarana khusus yang menunjang penyelenggaraan program pendidikan inklusi masih perlu diperhatikan, karena secara langsung
Evaluasi Program Pendidikan Inklusi Pada Pendidikan Dasar Sekolah Islam Fitrah Al Fikri Depok (Penerapan Model Evaluasi Stake)

ataupun tidak akan berpengaruh terhadap pelaksanaan program pendidikan inklusi.

\section{Transactions}

Perenecanaan pembelajaran disusun berdasarkan hasil identifikasi dan asesmen siswa. Berdasarkan hasil identifikasi dan asesmen, maka dapat dilakukan penyesuaian-penyesuaian terhadap kurikulum yang akan digunakan. Mulai dari penyesuaian pelaksanaan pembelajaran dan penilaian pembelajaran. Hasil identifikasi dan asesmen merupakan dasar acuan dalam menyusun rencana pembelajaran, maka dari itu proses identifikasi dan asesmen perlu mendapatkan menjadi perhatian khusus, karena dampaknya akan berpengaruh terhadap perencanaan pembelajaran, pelaksanaan pembelajaran bahkan sampai ke proses penilaian pembelajaran.

Pada pelaksanaan kegiatan pembelajaran yang masih perlu diperhatikan adalah penggunaan media pembelajaran yang sesuai dengan karakteristik dan kemampuan siswa $A B K$, hal ini berhubungan dengan pengadaan sarana dan prasarana dan alokasi dana khusus untuk menunjang proses pembelajaran inklusi. Begitu juga dengan penilaian pembelajaran yang menggunakan teknik penilaian sesuai dengan karakteristik dan kemampuan siswa ABK dibutuhkan alat khusus, hal ini juga berhubungan dengan pengadaan sarana dan prasarana dan alokasi dana khusus yang menunjang proses penilaian pembelajaran bagi siswa $\mathrm{ABK}$.

\section{Outcomes}

Hasil belajar siswa ABK diperoleh berdasarkan penilaian terhadap sistem kenaikan kelas/ kelulusan dan sistem pelaporan. Berdasarkan hasil studi dokumen bahwa pada setiap tahun tidak pernah ada kasus siswa $A B K$ yang tinggal kelas atau tidak lulus. Untuk laporan hasil belajar siswa $A B K$ di sekolah inklusi yaitu berupa laporan kualitatif ataupun kuantitatif. Hasil belajar yang biasa dilaporkan kepada orang tua siswa tidak hanya berupa angka-angka saja akan tetapi dilengkapi dengan uraian yang terperinci tentang pencapaian hasil belajar siswa ABK yaitu berupa perkembangan siswa pada setiap hari pembelajaran. 
Jajang Permana Jaya

Agus Dudung

Dinny Devi Triana

Beberapa rekomendasi yang diharapkan dapat bermanfaat bagi pihak-pihak terkait, yaitu: Bagi pemerintah disarankan untuk mengeluarkan kebijakan tentang program pendidikan inklusi terutama yang berhubungan dengan guru pendamping khusus dengan latar belakang PLB atau GPK yang mengikuti DIklat dan kurikulum khusus yang dapat digunakan dalam pembelajaran siswa ABK. Bagi Direktorat PSLB dan Dinas Pendidikan Kotamadya Depok, peneliti menyarankan untuk memberikan pelatihan-pelatihan

\section{Daftar Pustaka}

Aiken, Lewis R. Rating Scales and Checklist Evaluation Behavior Personality, and Attitude. New York : John Wiley \& Sons INc, 1996.

Arikunto, Suharsimi dan Cepi Safrudin Abdul Jabar. Evaluasi Program Pendidikan. Jakarta: PT Bumi Aksara, 2007.

Aripin, Zainal. Evaluasi Pembelajaran: Prinsip, Teknik, Prosedur Bandung: Remaja, 2007

David D. (20I2). Sekolah Inklusif Konsep dan Penerapan Pembelajaran (Edisi III),Terjemahan oleh Ny. Enrica Denis. Nuansa : Bandung

Direktorat Pembinaan PK-LK Dikdas : Jakarta Saifuddin Azwar. (20II).

Farida Yusuf Tayibnapis. (2008). Evaluasi Program dan Instrumen Evaluasi untuk Program Pendidikan dan Penelitian. Rineka Cipta : Jakarta Fitzpatrick, Jody L,

Geniofam. (2010). Mengasuh \& Mensukseskan Anak Berkebutuhan Khusus. Gerai Ilmu : Yogjakarta 17 Istiningsih. (2008).

Grounlund, Norman E.,dan Robert L. linn, Meausurement and Evaluation in Teaching. New York: Macmillan Publishing Company, 1990.

Guba, Egon G.,dan Yvonna S. Lincoln. Effective Evaluation Improving the Usefulness of Evaluation Result Trough Responsive and Naturalistic Approaches. California: Jossey Bass Inc 198I.
Evaluasi Program Pendidikan Inklusi Pada Pendidikan Dasar Sekolah Islam Fitrah Al Fikri Depok (Penerapan Model Evaluasi Stake)

bagi guru-guru tentang penanganan siswa $A B K$ pada sekolah penyelenggara program pendidikan inklusi. Bagi pihak pemerintah (Dit PSLB dan Dinas Pendidikan Kotamadya Depok) memberikan bantuan sarana dan prasarana dalam menunjang pelaksanaan pembelajaran. Bagi pihak sekolah, melakukan asesmen terhadap siswa $A B K$, pembelajaran yang sesuai dengan kebutuhan dan kemampuan peserta didik dalam optimalisasi partisipasi siswa $A B K$.

llahi, Muhammad Takdir. Pendidikan Inklusif (Konsep Dan Aplikasi). Jogjakarta: AR-RUZZ MEDIA, 2013.

James R. Sander \& Blaine R. Worthen. (2004). Program Evaluation Alternative Approaches and Practical Guidelines. Pearson Education Inc : Boston

Muhammad, Jamila K. A. Special Education For Special Children Panduan Pendidikan Khusus Anak-Anak Dengan Ketunaan dan Learning Disabilities. Jakarta Selatan:Hikmah PT Mizan Publika,2008.

Owen, John M. (2006). Program Evaluation Forms And Approaches.

Owen, John M. Program Evaluasi Form And Approaches. Sydney: Southwood Press, 1993.

Permendiknas Republik Indonesia Nomor 70 Tahun 2009 tentang Pendidikan Inklusif Peserta Didik yang memiliki Kelainan dan Memiliki Potensi CIBI. (20II).

Popham, James. Modem Educational Evaluation. New Jersey : Prentice Hall Inc, $198 \mathrm{I}$.

Sikap Manusia : Teori dan Pengukurannya (Edisi ke 2). Pustaka Pelajar : Yogjakarta Sapon-Shevin, Mara. (2007).

Smith, J.David. Konsep dan Penerapan pembelajaran sekolah Inklusi. Bandung:NUANSA,20I3.

Stubbs, Sue. (2002). Pendidikan Inklusif ketika hanya sedikit sumber. Terjemahan oleh Susi Septaviana. Universitas Pendidikan Indonesia (UPI) : Bandung 
Jajang Permana Jaya

Agus Dudung

Dinny Devi Triana

Stufflebeam, Daniel L, Madaus, George F, \& Kellaghan,

Suharsimi Arikunto \& Cepi Safruddin Abdul Jabar. (2009). Evaluasi Program Pendidikan Pedoman Teoritis Praktis Bagi Mahasiswa Praktisi Pendidikan. Bumi Aksara : Jakarta Smith,

Suharsimi Arikunto. (2009). Dasar-Dasar Evaluasi Pendidikan (Edisi Revisi). Bumi Aksara : Jakarta

Thomas (Eds). (2002). Evaluation Models Viewpoints On Education And Human Services Evaluation (Second Edition). Kluwer Academic Publishers : Boston
Evaluasi Program Pendidikan Inklusi Pada Pendidikan Dasar Sekolah Islam Fitrah Al Fikri Depok (Penerapan Model Evaluasi Stake)

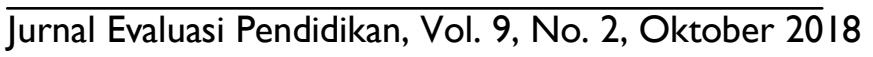

